\title{
Effect of Different Bag Opening Methods of Oyster Mushroom (Pleurotus ostreatus) on Growth Parameter, Yield and Benefit Cost Ratio
}

\author{
G. K. Upamanya ${ }^{1 *}$, R. Brahma ${ }^{2}$, R. Sarma ${ }^{3}$, P. Sharma ${ }^{4}$ and K. Das ${ }^{5}$ \\ ${ }^{1,4}$ Dept. of Plant Pathology, ${ }^{2}$ Dept. of Agronomy, ${ }^{5}$ Dept. of Entomology, ${ }^{3}$ Assoc. Dean, SCS College of Agriculture, Assam \\ Agricultural University, Rangamati, Dhubri, Assam (783 376), India
}

\section{Corresponding Author}

G. K. Upamanya

e-mail:gku_2003@yahoo.com

\author{
Article History \\ Article ID: IJEP0430a \\ Received on $01^{\text {st }}$ July, 2021 \\ Received in revised form on $06^{\text {th }}$ November, 2021 \\ Accepted in final form on $20^{\text {th }}$ November, 2021
}

\begin{abstract}
Oyster mushroom growers are generally confused about the scientific basis of the cultivation technology with regard to the best bag opening method after a spawn run. The present study was undertaken to find out the effect of four different methods of bag opening on yield, benefit cost ratio (BCR) and biological efficiency of oyster mushrooms during November, 2020 to March, 2021. The results indicated that treatment-2 (retaining the polythene bag for the entire cultivation period) exhibited significantly the highest yield (1644.61 $\left.\mathrm{g}^{\mathrm{bed}}{ }^{-1}\right)$ followed by treatment-3 (opening top part of the polythene bag after spawn run) (1536.62 $\mathrm{g} \mathrm{bed}^{-1}$ ), and treatment-1 (opening top and bottom part of the polythene bag (1468.82 $\mathrm{g} \mathrm{bed}^{-1}$ ) and treatment-4 (complete removal of the polythene bag) (1111.19 g). The BCR was also found to be the highest (4.39) in treatment-2 followed by treatment-3 (4.09), treatment-1 (3.96) and treatment-4 (2.98). Retaining the polythene bag during the entire cultivation period was found to be the best method of cultivation with regard to biological efficiency (82.23\%). Opening the top part of the polythene bag after the spawn run showed the biological efficiency of $76.83 \%$ which was followed by the treatment with opening the polythene bag from the top and bottom part of the bed (73.44\%). The lowest biological efficiency (55.56\%) was observed in the treatment in which the entire polythene bag was removed after a spawn run in darkroom. Mushroom growers may retain the polythene bag surrounding the mushroom bed during the entire cultivation period for better economic return.
\end{abstract}

Keywords: Biological efficiency, oyster mushroom, pinhead

\section{Introduction}

Oyster mushroom (Pleurotus spp.) belongs to the family of Tricholomataceae under Sub-division Basidiomycotina of Kingdom Fungi with exceptional lignolytic property (Machado et al., 2016; Li and Shah, 2016). Pleurotus consists of about 40 species distributed in the tropical and temperate regions out of which 26 can be cultivated successfully (Golak-Siwulska et al., 2018). The nutritionally gifted fungi now rank second among the important cultivated mushrooms in the world because of their low cost, easy to grow on a variety of agro wastes, high biological efficiency and nutrition value (Patel et al., 2012; Panjikkaran and Mathew, 2013; Mane et al., 2007; Sánchez, 2010). It is quite rich in protein, with all essential amino acids, minerals, fiber and poor in lipid (Lee et al., 2018; Eva et al., 2013; Purkayastha and Nayak, 1981). It is also considered as the most potential edible mushroom with high therapeutic and medicinal values (Mariga et al., 2014; Zhou et al., 2013; Kim et al., 2015; Yang et al., 2013). In India, the important commercially cultivated mushrooms are white button mushroom, Agaricus bisporus (Lange) Imbach (85.0\%) and oyster mushroom, Pleurotus spp. (24.1\%) (Sharma et al., 2019). The popularity of the oyster mushroom as a health food is increasing in the State of Assam and there is a huge scope for establishment of the potential market of this mushroom in the rural and urban area.The factors such as temperature, humidity and sterility of the substrates and their interaction determine the success of mushroom cultivation (Bellettini et al., 2019). The ideal climatic condition for cultivating oyster mushrooms in Assam starts from the month of September to February. High humidity prevails (80\%) in Assam during this period. However, the awareness program is very much important in successful dissemination of the knowledge of mushroom cultivation among rural community (Biswas, 2014). Simple and low-cost production techniques of cultivation of oyster mushroom using wide range of agro-substrate may be one of the reasons behind the popularity of oyster mushroom (Jegadeesh et al., 2018). As a result of the efforts of Krishi Vigyan Kendras (KVKs) of Assam in popularizing the venture of mushroom cultivation for self-employment by providing skill development training as well as demonstration programme among the rural youth, the popularity of the profession has 
gained momentum during the last 2-3 years. However, the oyster mushroom growers used different cultivation methods with regard to the opening of the bags. Some growers used to open the mushroom bag completely after the spawn runs for 2 weeks in a dark room, while others used to keep the mushroom bag intact for the entire cultivation period. The former technology was recommended by Assam Agricultural University (Upamanya, 1994) while the later was used by some of the experienced mushroom growers. However, there is confusion among the mushroom growers about the scientific basis of the cultivation technology with regard to bag opening methods. There are limited data in the literature concerning the mushroom yield and biological efficiency under different bag opening methods. Mamiro et al., (2014) observed better yield and biological efficiency in the mushroom beds with hanging plastic bags. There is an urgent need to know the effect of different bag opening methods on the yield and quality of oyster mushrooms in the prevailing climatic condition of Assam for benefit of mushroom growers in this region. The present study was conducted to find out the best method of bag opening after 15 days of spawn running in a dark room with reference to the growth parameters, yield, biological efficiency and economics of oyster mushrooms.

\section{Materials and Methods}

\subsection{Treatments}

The experiment was conducted in the Department of Plant Pathology, SCS College of Agriculture, Assam Agricultural University, Dhubri during the year 2020-21. Oyster mushroom, Pleurotus ostreatus was used in the experiment. The entire experiment was arranged in a randomized complete block design with 4 numbers of treatments replicated 10 times. The experiment was repeated 2 times for consistency of the result. The following treatment combinations were followed in the entire experiment.

$\mathrm{T}_{1}$ : Opening top and bottom part of the polythene bag 15 days after spawn running, $\mathrm{T}_{2}$ : Retaining entire polythene bag with 6-8 numbers of holes 15 days after spawn running, $T_{3}$ : Opening polythene bag from the upper surface of the bed 15 days after spawn running and $\mathrm{T}_{4}$ : Control (Complete removing the polythene bag 15 days after spawn running

The isolation of mother culture and preparation of spawn of $P$. ostreatus was done as per the method described by Hsu et al. (2018). The cultivation method up to the incubation (spawn running) step was followed as per the recommended method of Assam Agricultural University.

\subsection{Steps of cultivation}

The steps of cultivation using polythene bags are stated below.

\section{Step-I: Cutting and soaking of rice straw}

Well dried rice straw is chopped into $5-10 \mathrm{~cm}$ long pieces and soaked in cold water in a cauldron for 12 hours.

Step-II: Pasteurization of rice straw
Straw is pasteurized by steeping the straw in boiling water for 30 minutes. Straw is taken out and spread on a clean cement floor for cooling and draining the excess water from the substrate.

Step-III: Spawning

Two kilograms of rice straw (dry weight basis) was used for each bed. The size of the polythene bag should be in the dimension of $60 \times 60 \mathrm{~cm}^{2}$. Holes of $5 \mathrm{~cm}$ diameter are punched (except T-2, here 6-8 numbers of holes were made) in a polythene bag at a distance of $10 \mathrm{~cm}$. Two hundred grams of spawn i.e. $10 \%$ of the substrate (dry weight basis) was used for seeding each bed. The first layer of pasteurized straw was placed at the bottom of the polythene bag up to 8-10 $\mathrm{cm}$ depth and pressed properly. A layer of spawn (33 g) is sprinkled evenly above the first layer of the straw. Thus the polythene bag was filled with 6 layers of straw planked by 6 layers of spawn. The mouth of the polythene bag was loosely tied and kept in a spawn running room for 2 weeks.

Step-IV: Opening of the bags

Different bag opening methods were used based on the treatments used in the experiment and kept in a cropping room. In the cropping room, regular spraying with clean water was done on the mushroom bed for pinhead formation.

Step-V: Harvesting mushroom

The mushrooms were harvested before the cap begins to fold upward by twisting the stipe.

\subsection{Observations}

The following observations were undertaken during the entire experiment.

Number of days required for pinhead formation; Mushroom harvested $\left(\mathrm{gbed}^{-1}\right)$ in the first flush; Mushroom harvested $\left(\mathrm{gbed}^{-1}\right)$ in the second flush; Mushroom harvested $\left(\mathrm{gbed}^{-1}\right)$ in the third flush; Total yield in three flushes $\left(\mathrm{g} \mathrm{bed}^{-1}\right)$; Biological efficiency (total weight of fresh mushrooms divided by dry weight of substrate $\times 100$ ) and BCR.

\section{Results and Discussion}

\subsection{Yield bed $^{-1}$}

The results indicated that the growth parameters like the number of days required for pinhead formation, biological efficiency, yield per bed and the BCR in oyster mushroom production were influenced by different methods of the opening of the bag after complete spawn run in a dark room. Three numbers of harvests were considered for the calculation of yield per bed. With reference to the yield bed be $^{-1}$ it was observed from Table 1 that treatment-2 (retaining entire polythene bag with 6-8 numbers of holes 15 days after spawn run) recorded significantly the highest yield as compared to the rest of the treatments during the first and second harvest. Treatment-4 (complete removal of the polythene bag after spawn run) exhibited significantly the lowest yield per bed 


\begin{tabular}{|c|c|c|c|c|}
\hline \multirow[t]{2}{*}{ Treatments } & \multicolumn{4}{|c|}{ Yield bed ${ }^{-1}(\mathrm{~g})$} \\
\hline & $\begin{array}{c}1^{\text {st }} \\
\text { harvest }\end{array}$ & $\begin{array}{c}2^{\text {nd }} \\
\text { harvest }\end{array}$ & $\begin{array}{c}3^{\text {rd }} \\
\text { harvest }\end{array}$ & $\begin{array}{l}\text { (Total } \\
\text { yield) }\end{array}$ \\
\hline $\begin{array}{l}\text { Opening top and } \\
\text { bottom part of } \\
\text { the polythene } \\
\text { bag }\left(T_{1}\right)\end{array}$ & $598.57^{c}$ & $510.95^{b}$ & $359.23^{b}$ & $1468.82^{b}$ \\
\hline $\begin{array}{l}\text { Retaining entire } \\
\text { polythene bag } \\
\left(\mathrm{T}_{2}\right)\end{array}$ & $712.09^{a}$ & $541.60^{a}$ & $390.92^{\mathrm{a}}$ & $1644.61^{\mathrm{a}}$ \\
\hline $\begin{array}{l}\text { Opening top part } \\
\text { of the polythene } \\
\text { bag }\left(\mathrm{T}_{3}\right)\end{array}$ & $678.04^{b}$ & $490.19^{b}$ & $368.39^{\mathrm{ab}}$ & $1536.62^{b}$ \\
\hline $\begin{array}{l}\text { Complete } \\
\text { removal of the } \\
\text { bag }\left(T_{4}\right)\end{array}$ & $514.23^{d}$ & $356.86^{c}$ & $240.10^{c}$ & $1111.19^{c}$ \\
\hline$C D(p=0.05)$ & 33.11 & 27.94 & 24.63 & 95.58 \\
\hline
\end{tabular}

during first (514.23 g), second (356.86 g) and third (240.10 g) harvest. Treatment-3 (opening top part of the polythene bag after spawn run) was found to be the second best treatment during the first, second and third harvest. This was followed by treatment-1 (Opening top and bottom part of the polythene bag) in terms of yield in all the flushes. However, treatment- 2 and treatment- 3 was at par with respect to the yield bed ${ }^{-1}$ during the third harvest. With reference to the total yield bed ${ }^{-1}$, it was observed that treatment-2 exhibited significantly the highest yield (1644.61 $\mathrm{g} \mathrm{bed}^{-1}$ ) followed by Treatment-3 (1536.62 $\left.\mathrm{g} \mathrm{bed}^{-1}\right)$ and treatment-1 (1468.82 g bed $^{-1}$ ). The treatment- 4 (complete removal of the polythene bag) recorded significantly the lowest yield (1111.19 $\mathrm{g} \mathrm{bed}^{-1}$ ) among all the treatments. Our findings are in conformity with Mamiro et al. (2014) who observed significantly highest yield and biological efficiency in the bed where the clear polythene bag was used. The lowest yield per bed in the de-plastic beds may be due to exposure of large surface area resulted in drying of more numbers of pinheads as compared to the beds where polythene bags were retained for the entire cultivation period .

\subsection{Number of days required for pinhead formation}

Complete removal of the polythene bag (treatment-4) induces early pinhead formation as compared to other treatments (Figure 1). Treatment-3 (opening top part of the polythene bag) took the highest number of days for pinhead formation.

\subsection{Benefit cost ratio (BCR) of different treatments}

The benefit cost ratio ( $B C R$ ) was calculated for all the treatments and graphically presented in Figure 2 . The cost of cultivation per bed was the same for all the treatments. Due to the difference in yield per bed, the difference in the BCR was observed. The highest BCR (4.39) was observed in the

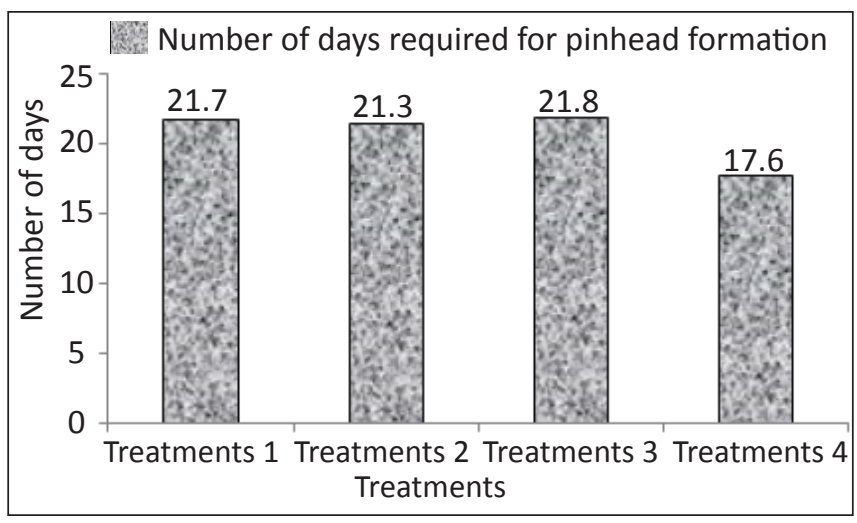

Figure 1: Number of days required for pinhead formation under different treatments

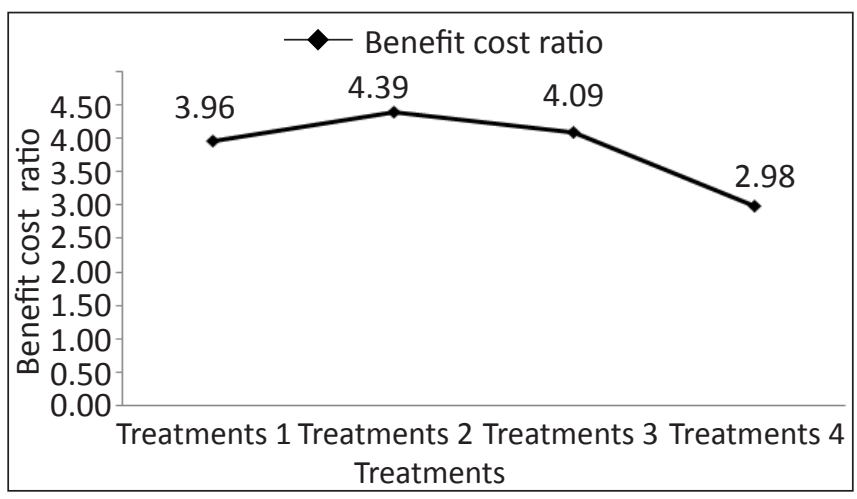

Figure 2: BCR of different treatments

treatment where the complete polythene bag was retained during the entire cultivation period. The treatment with removal of the top part of the polythene bag during cultivation period after spawn run resulted in the BCR of 4.09 which was followed by 3.96 in the treatment in which top and bottom part of the polythene bag was removed after spawn run. The lowest BCR (2.98) was observed in the de-plastic treatment.

\subsection{Biological efficiency}

The biological efficiency (total weight of fresh mushrooms divided by dry weight of substrate $\times 100$ ) was calculated and the result was depicted in Figure 3.

Biological efficiency was the highest $(82.23 \%)$ in treatment-2 (retaining the polythene bag for the entire cultivation period) followed by treatment-3 (76.83\%) and treatment-1 (73.44\%).

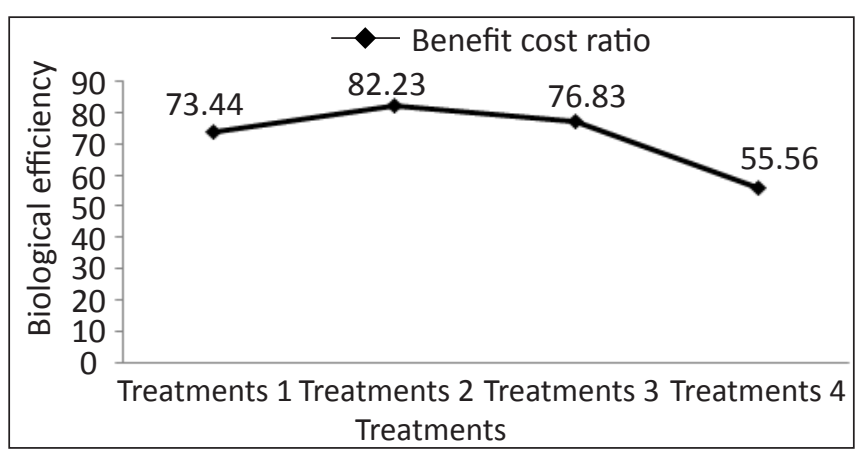

Figure 3: Biological efficiency of different treatments 
The lowest biological efficiency (55.56\%) was observed in the treatment in which the entire polythene bag was removed after a spawn run in darkroom. The difference in biological efficiency was due to the difference in the yield under different treatments.

\section{Conclusion}

The treatment, opening top and bottom part of the polythene bag in which the entire polythene bag was retained after spawn running was found to be the best followed by the treatment in which the upper surface of the polythene bag was removed after spawn running. The lowest yield and BCR were obtained from the de-plastic beds.

\section{References}

Bellettini, M.B., Barba, M., Fiorda, F.A., Maieves, H.A., Teixeira, G.L., Vila, S., Hornung, P.S., Junior, A.M., Ribani, R.H., 2019. Factors affecting mushroom Pleurotus spp. Saudi Journal of Biological Sciences 26(4), 633-646.

Biswas, M.K., 2014. Oyster mushroom cultivation: a women friendly profession for the development of rural West Bengal. International Journal of Bio-resource and Stress Management 5(3), 432-435. DOI:10.5958/09764038.2014.00594.6

Eva, S., Rohalova, L., Hedvigy, M., 2013. Semi-solid fermentation of Pleurotus ostreatus. Journal of Microbiology, Biotechnology and Food Sciences 2, 1950-1958.

Golak-Siwulska, I., Kaluzewicz, A., Spizewski, T., Siwulski, M., Sobieralski, K., 2018. Bioactive compounds and medicinal properties of Oyster mushrooms (Pleurotus sp). Folia Horticulturae 30(2), 191-201.

Hsu, C.M., Hameed, K., Van Cotter, T., Liao, H.L., 2018. Isolation of mother cultures and preparation of spawn for oyster mushroom cultivation. IFAS Extension. University of Florida, 1-6.

Jegadeesh, R., Lakshmanan, H., Kab-Yeul, J., Sabaratnam, V., Raaman, N., 2018. Cultivation of pink oyster mushroom Pleurotus djamor var. roseus on various agro-residues by low cost technique. Journal of Mycopathological Research 56(3), 213-220.

Kim, S.H., Jakhar, R., Kang, S.C., 2015. Apoptotic properties of polysaccharide isolated from fruiting bodies of medicinal mushroom Fomes fomentarius in human lung carcinoma cell line. Saudi Journal of Biological Sciences 22, 484-490.

Lee, S.J., Kim, H.H., Kim, S.H., Kim, I.S., Sung, N.J., 2018. Culture conditions of liquid spawn and the growth characteristics of Pleurotus ostreatus. Journal of Mushroom 16(3), 162-170.

Li, S., Shah, N.P., 2016. Characterization, antioxidative and bifidogenic effects of polysaccharides from Pleurotus eryngii after heat treatments. Food Chemistry 197, 240-249.
Machado, A.R.G., Teixeira, M.F.S., Kirsch, L.S., Campelo, M.C.L., Oliveira, I.M.A., 2016. Nutritional value and proteases of Lentinus citrinus produced by solid state fermentation of lignocellulosic waste from tropical region. Saudi Journal of Biological Sciences 23(5), 621-627.

Mamiro, D.P., Mamiro, P.S., Mwatawala, M.W., 2014. Oyster mushroom (Pleurotus spp.) Cultivation technique using reusable substrate containers and comparison of mineral content with leafy vegetables. Journal of Applied Bioscience. 80, 7060-7070.

Mane, V.P., Patil, S.S., Syed, A.A., Baig, M.M.V., 2007. Bioconversion of low quality lignocellulosic agricultural waste into edible protein by Pleurotus sajor-caju (Fr.) Singer. Journal of Zhejiang University of Science 8, 745-751.

Mariga, A.M., Yang, W.J., Mugambi, D.K., Pei, F., Zhao, L., Shao, Y., Hu, Q., 2014. Antiproliferative and immunostimulatory activity of a protein from Pleurotus eryngii. Journal of the Science of Food and Agriculture 94, 3152-3162.

Panjikkaran, S.T., Mathew, D., 2013. An environmentally friendly and cost effective technique for the commercial cultivation of oyster mushroom [Pleurotus florida (Mont.) Singer]. Journal of the Science of Food and Agriculture 93, 973-976.

Patel, Y., Naraian, R., Singh, V.K., 2012. Medicinal properties of Pleurotus species (Oyster mushroom): A review. World Journal of Fungal and Plant Biology 3(1), 01-12.

Purkayastha, R.P., Nayak, D., 1981. Analysis of protein patterns of an edible mushroom by gel electrophoresis and its amino acid composition. Journal Food Science and Technology 18, 89-91.

Sanchez, C., 2010. Cultivation of Pleurotus ostreatus and other edible mushrooms. Applied Microbiology and Biotechnology 85, 1321-1337. Doi: 10.1007/s00253009-2343-7

Sharma, A., Khanna, A.S., Raina, R., Kapoor, R., Thakur, K.S., 2019. Faunistic survey of insect-pests associated with Agaricus bisporus. International Journal of Economic Plants 6(3), 122-125. Doi: HTTPS://DOI.ORG/10.23910/ IJEP/2019.6.3.0321

Upamanya, G.K., 1994. Cultivation technology of oyster mushroom relevant to Jorhat condition. M.Sc (Agri) Thesis, Assam Agricultural University, Jorhat, Assam.

Yang, Z., Xu, J., Fu, Q., Fu, X., Shu, T., Bi, Y., Song, B., 2013. Antitumor activity of a polysaccharide from Pleurotus eryngii on mice bearing renal cancer. Carbohydrates Polymers 95, 615-620.

Zhou, J., Chen, Y., Xin, M., Luo, Q., Gu, J., Zhao, M., Xu, X., Lu, X., Song, G., 2013. Structure analysis and antimutagenic activity of a novel salt-soluble polysaccharide from Auricularia polytricha. Journal of the Science of Food and Agriculture 93, 3225-3230. 